\author{
Aleksandra Szyller \\ Uniwersytet Warszawski \\ szyllerola@gmail.com
}

\title{
Dyskurs podręcznikowy a dyskurs dziecięcy - odmienne postrzeganie rzeczywistości
}

\section{Summary \\ Textbook discourse and children's discourse - a different perception of reality}

Textbooks have become a source of assistance that settled for good into Polish education landscape, a measure without which many adults cannot imagine the school reality. At the same time, the lack of the comprehensive studies on education packs is noticeable. What is more, the voice of children in Poland is marginalized or completely ignored, as opposed to the Western countries. The perspective of the youngest participants of the education process, who are the direct recipients of the textbook offer and are critical and thoughtful, is very rarely taken into account. Whereas their opinions may be a source of very powerful changes in education.

This article presents my own research results. The topic of undertaken study was the analysis of the most popular education packs for classes 1-3. The gathered data was enriched with third-grade students' opinions about the tasks from the education packs and a description of their experiences related to the usage of those textbooks in school.

The study was conducted with a qualitative approach. As the study techniques, a documentary analysis and focus interviews (enriched with textbook tasks designed by children) were used. As resulting from the study, the textbook discourse is not a children's discourse. Authors of these textbooks tend to forget about the real needs and capabilities of children. Students appeal for taking into account their high potential and putting into the textbooks subjects and tasks fitted to their development level, allowing them to take creative and divergent actions.

Słowa kluczowe: podręcznik, dyskurs dziecięcy, dyskurs podręcznikowy, konwergencyjność zadań, myślenie odtwórcze, zniewolenie

Keywords: textbook, children's discourse, textbook discourse, convergence of tasks, noncreative thinking, imposition

\section{Wprowadzenie}

Istnieje środek dydaktyczny obdarzony magiczną siłą, bez którego wielu nauczycielom, ale także rodzicom, trudno wyobrazić sobie współczesną edukację. Podręcznik, który trwale wpisał się w krajobraz polskiego szkolnictwa, stał się dziś symbolem poznawczej aktywności dziecka, miernikiem realizacji programu, wyznacznikiem skuteczności dzia- 
łań edukacyjnych. Stworzony do poprawy rezultatów procesu kształcenia, przeobraził się w pomoc ograniczającą, bezlitośnie wyznaczającą rytm uczniowskiej pracy, determinującą każdy krok dziecka na zajęciach szkolnych, zyskującą status uświęconego materiału. Hasło „Otwórzcie PODRĘCZNIKI” będące egzemplifikacją tzw. biernego startu, stało się fundamentem szkolnego rytuału (Zalewska 2014).

Także w edukacji wczesnoszkolnej, w której przede wszystkim warto opierać się na bezpośrednim poznaniu, spontanicznej, badawczej aktywności dziecka, praktycznym działaniu, widać coraz powszechniej i na większą skalę uprawianą przez nauczycieli kartomanię. Wśród nauczycieli i rodziców panuje stereotyp, że im więcej ćwiczeń wypełnią dzieci, tym więcej będą wiedzieć (Zimny 1995). Mało kto zastanawia się jednak nad sensem i efektywnością takiej pracy, jej rzeczywistymi rezultatami, konsekwencjami zdecydowanie odbiegającymi od zamierzonych.

Brakuje kompleksowych badań, których przedmiotem zainteresowania stałby się podręcznik. Co więcej, niezmiernie rzadko uwzględnia się w nich perspektywę najmłodszych uczestników edukacji, do których oferta podręcznikowa jest bezpośrednio adresowana. W Polsce, w przeciwieństwie do krajów zachodnich, głos dzieci jest często marginalizowany lub całkowicie pomijany. Tymczasem uczniowie, bezpośredni uczestnicy procesu edukacyjnego, odbiorcy oferty podręcznikowej są wrażliwymi, refleksyjnymi i niezwykle krytycznymi obserwatorami. Można pozyskać od nich wiele istotnych informacji dotyczących rzeczywistości szkolnej, które mogą stać się jednocześnie potężnym katalizatorem zmian w edukacji.

\section{Założenia i metodologia badań własnych}

Przedmiotem podjętych badań była analiza najpopularniejszych podręczników zintegrowanych dla edukacji elementarnej (w zakresie edukacji językowej, matematycznej i przyrodniczej). Wyniki analiz pakietów edukacyjnych zostały rozszerzone o sądy trzecioklasistów dotyczące podręcznikowych treści oraz opis ich doświadczeń związanych $\mathrm{z}$ używaniem tego środka w szkole.

Badania przeprowadzono przy zastosowaniu podejścia jakościowego. Jako metody gromadzenia danych wykorzystano analizę dokumentów oraz wywiady fokusowe. Badania $\mathrm{z}$ udziałem trzecioklasistów pogłębione zostały egzemplifikacją powstałych w ich toku wytworów - samodzielnie zaprojektowanych przez dzieci zadań podręcznikowych.

Wyniki badań opisane w niniejszym artykule odnoszą się do następujących pytań badawczych:

1. Jakie rodzaje zadań i ćwiczeń z zakresu edukacji językowej, matematycznej i przyrodniczej znajdują się w pakietach edukacyjnych?

2. Jakie umiejętności dzieci są aktywizowane i doskonalone w pracy z podręcznikiem?

3. Co sądzą uczniowie na temat zadań i ćwiczeń prezentowanych w podręcznikach?

4. Jakie zmiany w podręcznikowych treściach i tematach proponują uczniowie?

W badaniach wzięło udział dwanaście szkół z województwa mazowieckiego. Przeprowadzono trzydzieści sześć wywiadów fokusowych wśród dwustu sześćdziesięciu czterech 
uczniów z dwunastu klas trzecich. Wywiady grupowe, otwarte rozmowy z uczniami zrealizowano za zgodą, ale bez obecności nauczycieli - wychowawców klas. Wytwory dziecięce powstałe w trakcie badań nie były analizowane jako przedmiot badań. Stanowiły raczej egzemplifikacje wypowiedzi uczniów. Łącznie powstały sto trzydzieści dwie prace.

\section{Dyskurs podręcznikowy, czyli „elementarz” widziany oczami dorosłego}

Infantylizacja treści w edukacyjnych pakietach jest prawdopodobnie jednym z najczęściej pojawiających się zastrzeżeń. Złamanie zasady przystępności, dopasowania treści zawartych w podręcznikach do wiedzy i umiejętności uczniów, może być sygnałem świadczącym o braku wiary dorosłych w wiedzę, możliwości i doświadczenie dziecka. Zdecydowana większość podręcznikowych poleceń leży w strefie aktualnego, a nie najbliższego rozwoju (Wygotski 1971). Do typologii Wygotskiego można by dodać dziś jeszcze jedną, niewyróżnioną przez pedagoga strefę - rozwój miniony, w którą z powodzeniem można wpisać niektóre z podręcznikowych treści. Śmiało, choć ze wstydem można stwierdzić, że próbując dostosować się do odgórnych standardów, podstawy programowej, wewnątrzszkolnych programów, oczekujemy od dzieci czegoś, co już dawno opanowały. Wydaje nam się, że wiemy lepiej, co i kiedy powinni umieć uczniowie. Normalizujemy podejście do ich umiejętności, uważając podstawę programową za pułap ich możliwości. W rezultacie uprawiamy swoistą pseudoedukację, marnotrawimy czas (nie tylko swój, ale przede wszystkim dzieci), doprowadzając do daleko posuniętego regresu (Żytko 2014).

Pracując z podręcznikiem w klasie pierwszej, dzieci dowiadują się, że krowa robi $m u$ i daje mleko, kura woła ko, ko i znosi jajka, owca becząc produkuje wełnę. W innych ćwiczeniach dzieci kolorują najmniejsze i największe przedmioty, skrajnie różniące się od siebie rozmiarem; patrząc na kobietę spacerującą jesienią po parku w kostiumie kąpielowym, oceniają, czy jest ona ubrana w sposób dostosowany do pogody. Poszerzając zasób słownictwa o przyimki, rysują dwa tulipany na łące i dodają skowronka fruwającego nad polem. Układając proste, statyczne obrazki w kolejności, dokonują antycypacji i dorysowują oczywiste zakończenie. Tak daleko idące uproszczenie treści w podręczniku skierowanym do dzieci w wieku wczesnoszkolnym budzi ogromne wątpliwości. Omawiany tu materiał z powodzeniem nadaje się dla trzylatka.

Podobne zabiegi zdają się nie mieć końca. Skutecznie zniechęcają ucznia do nauki, utrzymując go w przeświadczeniu, że w szkole i tak nie można dowiedzieć się niczego, czego by nie wiedział. Dziecko wdraża się do stosowania rozmaitych destrukcyjnych strategii przetrwania, utwierdza w przekonaniu, że chwalenie się wiedzą osobistą może spotkać się z nieprzychylnym spojrzeniem nauczyciela, który wolałby uczyć w przeświadczeniu, że wprowadzane przez niego informacje są dla dzieci całkowicie nowe, nieznane i jakże interesujące.

„[Uczniowie] przekonują się, że szkoła jest dziwnym miejscem, gdzie człowiek często musi udawać, że nie umie i nie wie, bo jego umiejętności i wiedza są źle widziane. (...) W ich umyśle powstaje schizofreniczny model wiedzy podzielonej na szkolną i pozasz- 
kolną. A uczenie się zaczyna przypominać uczestnictwo w dziwnych rytuałach, mających swoje uzasadnienie w niejasnej dla nich tradycji, ale pozbawionych logiki i związku z życiem" (Klus-Stańska, Nowicka 2012: 22).

Podręczniki są dziś jednym z najpotężniejszych narzędzi utrwalających w uczniach niesłuszne przekonanie, że na każde pytanie można znaleźć tylko jedną poprawną odpowiedź. Terror jednej odpowiedzi i nacisk na problemy konwergencyjne są jednymi z najpoważniejszych czynników odpowiedzialnych za blokowanie rozwoju wyższych procesów poznawczych uczniów (Szmidt 2013). Trudno nie zgodzić się z jednym z najważniejszych odkryć psychologicznych autorstwa Guilforda, że skrajnie inaczej myślimy rozwiązując problemy otwarte niż dokonując namysłu nad pytaniami zamkniętymi (Michael 2013). Niestety ciągle brak w podręcznikach kreatywnych, dywergencyjnych zadań inspirujących do twórczej pracy, własnego, nieskrępowanego działania, myślenia krytycznego, otwartego i heurystycznego. W pytaniach, ćwiczeniach i poleceniach, nie tylko językowych, ale także matematycznych i przyrodniczych, dominuje behawioryzm, spuścizna szkoły transmisyjnej, nauczanie po śladzie. Wszystko to kosztem konstruktywizmu i jego praktycznej realizacji. Zadania konwergencyjne obecne w pakietach motywują przede wszystkim do wydobycia z pamięci poszukiwanych treści, wymagając jedynie ich poprawnego odtworzenia. Uczenie się to głównie podążanie za poleceniami typu wstaw, podkreśl, podpisz, połacz, uzupetnij korzystając z wyrazów z ramki, rozpisz wg wzoru. Większość z nich to czynności proste, mechaniczne, niewymagające złożonych strategii działania (Zalewska 2008). Uczeń traktowany jest jak tabula rasa, puste naczynie, gotowe i chętne do napełnienia po brzegi „złotym napojem” przygotowanym przez autorów i wydawców.

Aspekt techniczny dominuje przede wszystkim w zadaniach mających na celu kształtowanie elementarnych umiejętności czytania, pisania i liczenia. Prowadzą one do ujednolicenia działań dzieci, herbartowskiej pracy jednym frontem. Nie ma tu miejsca na indywidualizację, uwzględnienie różnego stopnia wiedzy, poziomu umiejętności i doświadczeń uczniów. Wszyscy w tym samym tempie robią to samo, korzystając przy tym z tego samego koloru kredki. W większości zadań istnieje tylko jedna poprawna odpowiedź, jeden sposób wypełnienia zadania. Najlepiej byłoby, gdyby dzieci udzieliły jej w tym samym czasie.

Konwergencyjność zadań w podręcznikach w dużej mierze opiera się na formule tworzenia przez ucznia wypowiedzi ze zgromadzonych przez autorów wyrazów. Nawet w ćwiczeniach, w których celem dziecka jest wyjście poza dostarczone informacje, antycypowanie i wymyślanie ciągu dalszego historii, ogranicza się jego wypowiedź do przygotowanych uprzednio wyrazów. Brak tu miejsca na kreatywność, spontaniczne, nieskrępowane narzuconymi ramami wnioskowanie ucznia (Szyller 2016). Ortograficzna i gramatyczna poprawność wypowiedzi zdaje się przesuwać na dalszy plan jej komunikacyjną i semantyczną wartość (Zalewska 2008).

Co gorsze, konkretna pula wyrazów, możliwych do użycia przy udzielaniu odpowiedzi na pytanie podawana jest także w zadaniach wymagających wyrażenia „subiektywnej” opinii przez ucznia. Autorzy skutecznie narzucają własne poglądy, „właściwe” sposoby 
interpretacji wierszy, ilustracji, obrazków i czytanek. Brak jest miejsca na sformułowanie dziecięcej, niezdeterminowanej charakterem i strukturą polecenia oceny. Forsuje się także określone z góry postawy. W poleceniach typu oceń, opisz itp. mamy do wyboru szereg przymiotników, których musimy użyć, aby opisać dany przedmiot czy zjawisko. Wymuszają one niejako jedną, prawidłową odpowiedź, tym samym jedno możliwe do wyrażenia zdanie (Zalewska 2008). Co więcej, nierzadkie są elementy przemocy emocjonalnej, w których narzuca się pożądaną relację z ludźmi czy przedmiotami.

Konwergencyjność pojawia się głównie w zadaniach związanych z wprowadzaniem opisu. O ile do określenia charakteru bohatera literackiego trzeba wykorzystać wiedzę z przeczytanej książki i na pewno nie wszystkie przymiotniki z ramki będą do tego odpowiednie, o tyle do opisu własnego taty można użyć niemal każdego przymiotnika odnalezionego w słowniku języka polskiego. Dziecko pozbawione możliwości opowiedzenia o własnym ojcu przestaje widzieć sens wykonywania zadania. Tylko wiedza skontekstualizowana może być przez nie zasymilowana. Ponownie ujawnia się przepaść między tym, co szkolne, a tym, co rzeczywiste. Podręcznikowy tata może być pomysłowy, odważny, wesoły, na szczęście także zmęczony. Takie przymiotniki, jak smutny, chory czy zniecierpliwiony prawdziwemu ojcu jednak nie przystoją. W rezultacie, ograniczając dziecko do użycia części mowy wypisanych w ramce otrzymujemy niezwykle uproszczony, stereotypowy opis książkowego taty, nieistniejącego i bardzo dalekiego od rzeczywistości. Podobne zadania doprowadzają do pozornego kształtowania umiejętności językowych przy jednoczesnym zatraceniu celowości nauki języka. Dyskurs podręcznikowy po raz kolejny okazuje się nie być dyskursem dzieci w wieku wczesnoszkolnym. Edukacja zaś ustępuje miejsca indoktrynacji. „Celem edukacji jest pobudzenie do krytycznego myślenia dzięki przekazywanym informacjom. Celem indoktrynacji zaś jest wyeliminowanie z procesu poznania racjonalnych uzasadnień i argumentów. Skuteczne zastosowanie indoktrynacji sprowadza się więc do bezrefleksyjnego opanowania pojęć, zasad i reguł jakiegoś działania" (Wróbel 2007: 150-151).

Zastosowanie odtwórczej metody wykorzystywania wyrazów z ramki do konstruowania wypowiedzi widoczne jest także w częściach przyrodniczych pakietów. Dziecko zamiast inspiracji do śledzenia zmian w przyrodzie w warunkach naturalnych, konstruowania własnych dzienników obserwacji, przeprowadzania obserwacji i eksperymentów, stawiania hipotez i szukania na nie odpowiedzi, motywowane jest do opisu odbiegającego od rzeczywistości pseudoprzyrodniczego obrazka z obligatoryjnym wykorzystaniem przygotowanych przez autora wyrazów. Zamiast manipulowania przedmiotami, badania ich właściwości, uczniowie ograniczani są do piagetowskiego werbalizmu obrazkowego, oglądania eksperymentów na zdjęciach udostępnionych na kartach podręcznika. W skrajnych przypadkach, zamiast hodować i podlewać rośliny, naklejają obrazki przedstawiające przedmioty potrzebne do ich uprawy (Szyller 2016).

Narzucenie jednej wizji rozwiązania zadania $\mathrm{z}$ powodzeniem odnajdujemy także w przypadku realizacji treści matematycznych. Najczęściej spotykaną strategią rozwiązania zadania jest przedstawienie go na obrazku. Narzuca się tym samym brunerowski 
poziom ikoniczny. Nie bierze się pod uwagę faktu, że w zależności od poziomu rozwoju, umiejętności i doświadczeń, uczniowi może być łatwiej wykorzystać inną metodę, obliczając wynik w pamięci (poziom symboliczny), czy manipulując konkretnymi przedmiotami (poziom enaktywny) (Bruner 1978). Dla dziecka, które od razu obliczyło poprawny wynik bezcelowe i bezsensowne wydaje się rysowanie odpowiedzi (nie wspominając już o pseudowartości konieczności udzielenia odpowiedzi pełnym zdaniem, tzw. formalizmie językowym). Tam, gdzie tylko jest to możliwe uczeń powinien móc dojść do rozwiązania samodzielnie. Najlepsza metoda to ta, którą dziecko odkryło samo. Oznacza to nauczanie w poszukiwaniu śladu, a nie podążanie po nim. Nie ma potrzeby i uzasadnienia dla narzucania uczniowi sporządzania rysunku do każdego zadania tekstowego, z którym się zmierza. Problematyczne jest także wymaganie wykonania serii kolejnych działań matematycznych według jednego, przedstawionego przez nauczyciela wzoru. Zastanawiające jest to, czy takie zabiegi wpływają pozytywnie na wykształcenie zaradności arytmetycznej u dziecka, umiejętność budowania własnych strategii.

\section{Dyskurs dziecięcy, czyli „elementarz” widziany oczami dzieci}

Zgodnie $\mathrm{z}$ wypowiedziami dzieci w podręcznikach znajduje się zbyt dużo zadań trywialnych, zbyt prostych, niedostosowanych do ich możliwości poznawczych, poziomu rozwoju.

„Bo ten podręcznik niczego nie uczy, to jest po prostu podręcznik dla przedszkolaka. Skandal."

Stopień trudności prezentowanych zagadnień zdaje się odbiegać od szerokiej wiedzy uczniów. Co gorsza, „ciągnie je w dół”. Zdaniem trzecioklasistów największa przepaść między umiejętnościami uczniów a poziomem zadań widoczna jest w klasie pierwszej.

„W pierwszej klasie była taka książka kaligrafia, gdzie się piszę a, a, a i to jest nudne. Wszystkie dzieci krzyczały, jak Pani kazała wyjąć te zeszyty. Ciągle ta sama litera”. „To było takie monotonne. Wiemy wszystko i musimy przepisywać. I literę A przez dwadzieścia razy” „Mnie to wkurzało. Od tego ręka może zaboleć.”

Jak twierdzą uczniowie, problem infantylizacji treści nie znika również w starszych klasach edukacji wczesnoszkolnej. Dzieci czują się zmuszane do pozornej nauki umiejętności, które dawno już posiadły. Uczą się tego, co już wiedzą, nie dowiadują się tego, co chciałyby wiedzieć. W mury szkolne wkrada się nuda, brak poczucia sensu i motywacji do działania (Szyller 2016). Materiał zdaniem dzieci zbyt często jest powielany. W kolejnych klasach brakuje nowych, niepoznanych jeszcze informacji. Uczniowie powtarzają to, czego uczyli się w klasach młodszych.

„Na początku każdej książki mamy powtórkę z pierwszej i drugiej klasy. I to jest nudne, takie łatwe, że się nawet nie chce myśleć. I nie lubimy, że się nudzimy. Są rzeczy za proste. 
A za trudne? Nie, nie ma. I że jak jest dodawanie jeden plus pięć, to jest za proste. Takie są np. działania w matematyce. Banalne”. „My to wszystko wiemy”. „Uczymy się ciągle o tym samym. A tego czego nie wiemy, się nie dowiadujemy”. „Po co się tego uczę, jak już wszystko wiem?” „Jeżeli są łatwe zadania, to mi się tak za bardzo nie chcę odrabiać, np. 5 razy 5. W trzeciej klasie. No proszę. Tak i co chwila są te same".

Badani uczniowie apelują o włączenie do edukacji trudniejszych zadań i ćwiczeń. Mają motywację do konfrontowania się z problemami, których rozwiązanie nie byłoby oczywiste, stanowiłoby wyzwanie.

„Ja nie lubię zadań z treścią. Są za łatwe. Banalne. Powinny być takie, żeby pomyśleć”. „Ja lubię najtrudniejsze. Bo inne są za proste. Tak i nudne”. „Chciałbym, żeby książka stała się $35 \%$ bardziej poważna. Po prostu my się już starzejemy”. „A ja lubię z matmy wszystkie działania robić i takie dodatkowe głównie. Takie z tyłu i takie z wykrzyknikiem”.

Uczniowie wskazują także na brak różnorodności treści w podręcznikach, multiplikowanie zadań kształcących te same umiejętności na kilku, a nawet kilkunastu stronach „elementarza”. Konieczność uzupełniania od deski do deski każdego ćwiczenia w podręczniku bazującego na doskonaleniu tych samych umiejętności, skutkuje brakiem czasu na inne, znacznie bardziej wartościowe zdaniem dzieci aktywności.

„Za dużo jest tych działań na jednej stronie, a my robimy po kilkaset. I nie ma czasu na inne rzeczy, np. rysowanie”. „W podręcznikach jest mierzenie sześć dodać trzy centymetry. Na chwilę to jest fajne, ale tego jest za dużo. Sto takich stron”. ,Jest za dużo działań. My to już wiemy, a dalej musimy robić to samo. Tak i tak w kółko”. „I z matematyki jest tak, że na górze jest zadanie i dwie strony na ten sam temat, dotyczące tego samego".

Trzecioklasiści odrzucali wszelkie ograniczenia w samodzielnych wypowiedziach pisemnych. Wykazywali motywację do pisania na kreatywne, otwarte tematy. Sami chcieli decydować nie tylko o treści, ale także o konstrukcji, kompozycji swoich prac. Narzucone schematy uważali za nudne.

„Nie lubimy takich (zadań), gdzie jest dziura na wyraz. Są głupie. I za proste, nawet myśleć nie trzeba. Od razu wiadomo, co trzeba wstawić”. „Ja lubię pisać na dowolny temat. Najlepsze są rzeczy wymyślone. Jak możemy sami zadecydować”. „Ja bym chciała wymyślanie bajek”. „Opowiadanie o niesfornym Ó. No ludzie, to jest nudne. Wolałabym opowiadania swoje wymyślane, np. bajki z głowy, z komiksów. A nie takie z wyrazów”.

Uczniowie chcieli mieć możliwość dzielenia się z innymi własnymi zainteresowaniami, upodobaniami, planami i doświadczeniami.

„Żeby najpierw mówić, co się chce najbardziej robić w przyszłości i o tym gadać. O zawodach, o doświadczeniach”. „Lubimy np. opisać naszego najlepszego kolegę”. „Żeby można było napisać o tym, co lubimy. O naszym hobby. Ja się interesuje komputerem, a nie mogę o tym pisać". 


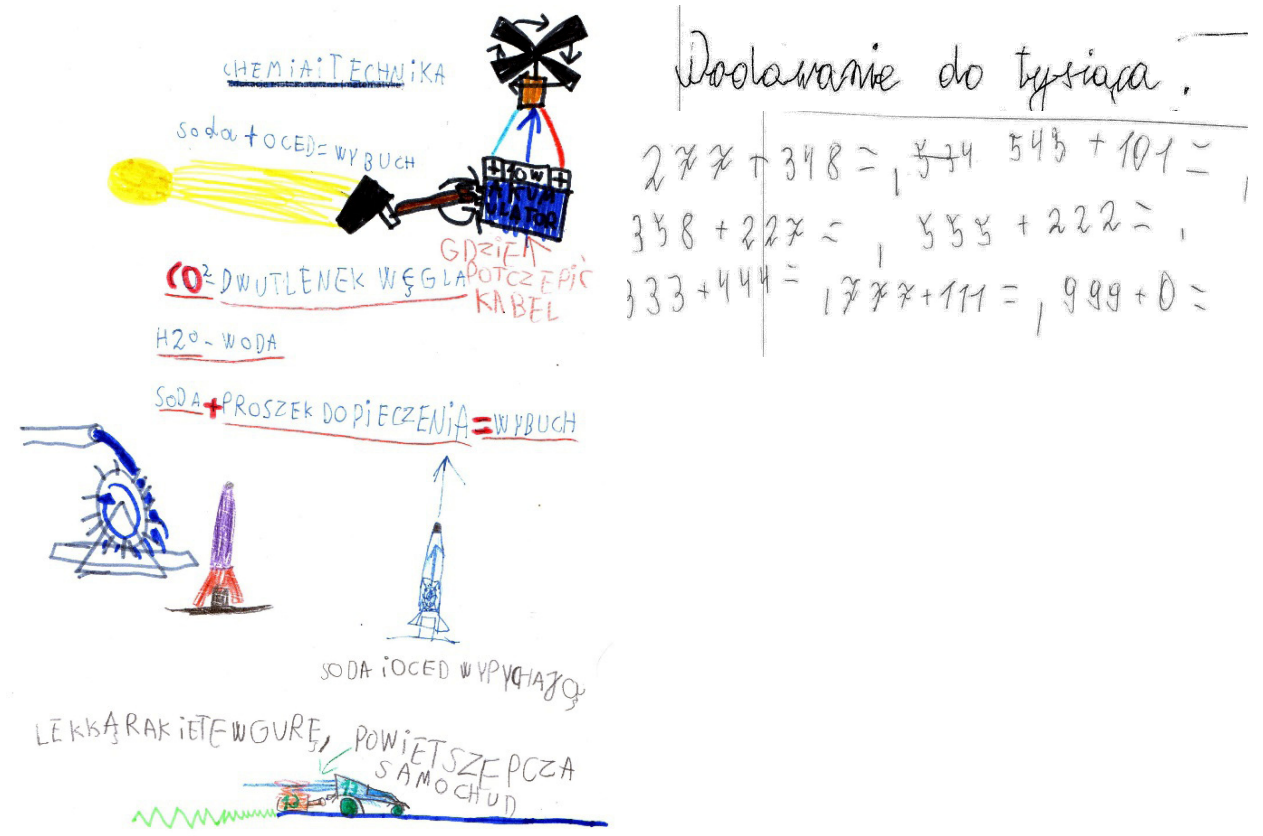

Rysunek 1. Zadania i rysunki świadczące o dużej wiedzy osobistej dzieci. Swoisty apel o odinfantylizowanie podręczników

Najpopularniejsze spośród zadań zamkniętych, a więc ćwiczenia z lukami wyrazowymi i literowymi badani uważali za uwsteczniające, jałowe i nudne, zdecydowanie zbyt często wykorzystywane przez autorów podręczników.

„Ja nie lubię takiego czegoś jak mamy taki tekst i wpisujemy tylko wyrazy, a Pani nam potem każe wszystko przepisać do zeszytu”. „Albo litery z ortografii do pustych okienek wpisujemy całą lekcję. To jest fu".

Najbardziej znienawidzonym przez dzieci zadaniem konwergencyjnym było obliczanie działań z koniecznością rozpisywania. Uczniowie definiowali je jako „zniewolenie”, marnotrawstwo czasu. Nie widzieli celu ich wykonywania. Twierdzili zgodnie, że tego typu zadania, pojawiając się nagminnie w podręcznikach, zniechęcają ich skutecznie do dalszej pracy z książką.

„Ja chciałem powiedzieć, że słabe jest rozpisywanie, bo bardzo dużo osób się na to skarży. Sto osób. Nienawidzę rozpisywać”. „A po co jak ja naprzód znam wynik”. „Ja bym chciał odpowiedź prostą i już. Świat to nie jest przecież niewola. II wojna światowa minęła”. „Pani mówi, że mam dopełniać. Te wszystkie sposoby długie na dodawanie i odejmowanie to jest strata czasu po prostu”. „Wiemy, jaki jest wynik. To po co to robimy? Ja chciałam napisać normalnie, a tata mówi, że wszystko mam dobrze, ale mam to rozpisać. Szkoda czasu na wszystko". 
Dzieci chciały móc wykonywać obliczenia w pamięci. Pragnęły być traktowane na miarę swoich możliwości, z uwzględnieniem ich potencjału intelektualnego.

„Mi też rozpisywanie się nie podoba. Wolałbym obliczyć w pamięci i obliczyć wynik, a tak siedzę nad pracą domową. Bez sensu, bo jestem bardzo dobry z matematyki i raczej bym go znał”. „Umiemy w pamięci. Nie jesteśmy głupi”. „Najbardziej lubię jak jest dwieście dodać dwieście i trzeba w pamięci".

Badani wnioskowali o pozostawienie im możliwości korzystania z własnych strategii, sposobów rozwiązania zadania.

„Wolę swoim własnym sposobem, ale bez rozpisywania. Dowolnym sposobem”. „Czasami mamy dwie strony rozpisywania, jednym sposobem napisanym w przykładzie. I to jest masakra. Ja np. szybko liczę i wolę w pamięci”. „Ja wolę, jak można wszystkimi możliwymi, a nie można".

Swoje zdanie potwierdzali w samodzielnie projektowanych zadaniach do podręczników.
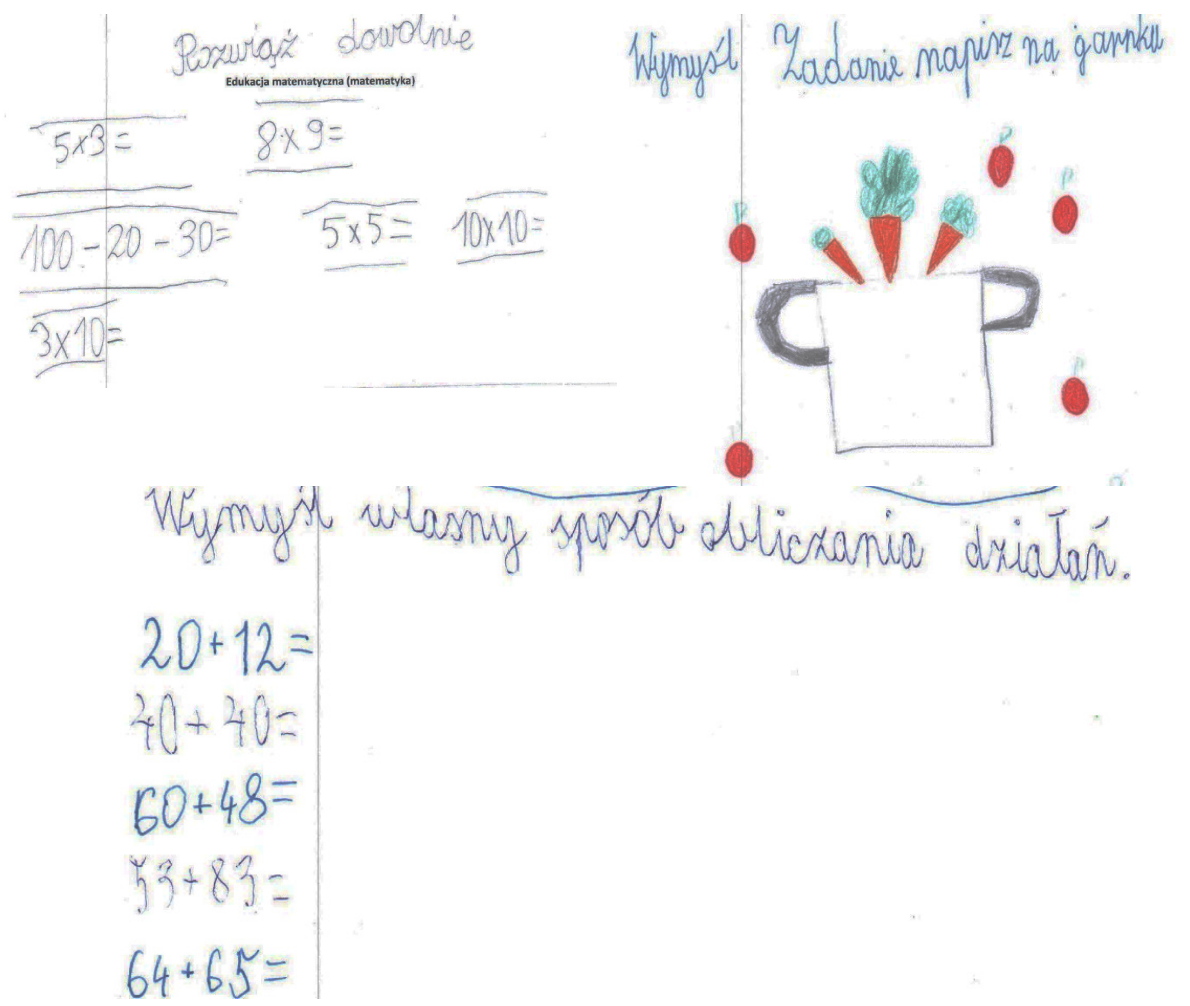

Rysunek 2. Zadania zaprojektowane przez uczniów uwidoczniające potrzebę samodzielnego, kreatywnego działania, odrzucenie ograniczeń. 
Zdaniem uczniów w podręcznikach brakuje wielu tematów, które są dla nich niezwykle interesujące. Dzieci apelują o włączenie do pakietów edukacyjnych zagadnień związanych ze sportem, ciałem człowieka, międzykulturowością, geologią, geografią, przyrodą, historią, polityką, techniką, robotyką, wynalazkami, chemią, fizyką i matematyką. Przytoczone w poniżej tabeli wypowiedzi dzieci świadczą o ich ogromnej wiedzy i potencjale. Wskazują na to, że współczesna szkoła zdaje się nie nadążać za potrzebami nowych uczniów.

Tabela 1. Proponowana przez uczniów tematyka, która zdaniem dzieci zbyt rzadko pojawia się w podręcznikach, wraz z jej konkretnymi egzemplifikacjami

\begin{tabular}{|c|c|}
\hline Proponowana tematyka & Wypowiedzi dzieci \\
\hline sport & $\begin{array}{l}\text { „I sport jest fajny, ale mało jest takich rzeczy”. „Sportu w ogóle nie } \\
\text { ma w podręczniku”. }\end{array}$ \\
\hline ciało człowieka, ewolucja & $\begin{array}{l}\text { „Ciało człowieka, gdzie są żyły, niebieskie i czerwone”. „Ja bym } \\
\text { wolał o budowie człowieka, o anatomii”. ,Jak powstał. Najpierw } \\
\text { jakaś zwierzyna utraciła ogon itd. Jak powstawały mięśnie i świat”. }\end{array}$ \\
\hline międzykulturowość & $\begin{array}{l}\text { "Ja bym chciała, że jakby było o innych krajach, to jak oni obchodzą } \\
\text { święta. Ja się nauczyłam na zajęciach dodatkowych, że w Meksyku } \\
\text { inaczej obchodzi się święta niż w Polsce”. „Np. ja oglądałem taki } \\
\text { film, że był taki lud, że jak dżungle giną, to tacy ludzie też giną. } \\
\text { I oni nie mają ubrań”. „O tradycjach”. „Żeby było więcej o religiach } \\
\text { świata”. }\end{array}$ \\
\hline $\begin{array}{l}\text { nauka o zwierzętach } \\
\text { i roślinach (przyroda) }\end{array}$ & $\begin{array}{l}\text { „Byśmy chcieli o zwierzętach więcej. Tak, przyrody } \\
\text { w podręcznikach w ogóle nie ma”, } \\
\text { „Tak o przyrodzie nie wiemy nic. Coś tam tak, ale nie dowiadujemy } \\
\text { się w szkole”. }\end{array}$ \\
\hline geologia, geografia & $\begin{array}{l}\text { „Ja bym chciała, żeby w szkole było jeszcze o sprawdzaniu } \\
\text { minerałów. Geologia”. „Tak, o kryształach, żeby było. O jaskiniach”. } \\
\text { „Bursztyny”. „O kamieniach szlachetnych”. }\end{array}$ \\
\hline historia, polityka & $\begin{array}{l}\text { „O polityce nie ma”. „Bo to jest interesujące, powinniśmy wiedzieć, } \\
\text { co się dzieje”. „Ja bym chciała bardzo rozmowy, że Putin nie będzie } \\
\text { jadł naszych jabłek. Tak, że zjemy jabłka na złość Putinowi”. „Tak, } \\
\text { że Ukraina i Rosja biją się o Krym. To wiecie, co się dzieje na } \\
\text { świecie. Ale nie ze szkoły, od rodziców”. „Ja bardzo chciałbym } \\
\text { o wyborach na prezydenta”. }\end{array}$ \\
\hline chemia, fizyka & $\begin{array}{l}\text { „Chciałabym, żeby w naszej klasie wprowadzili fizykę”. „Ja bym } \\
\text { wolała, żeby od trzeciej klasy wprowadzili chemię”. } \\
\text { „I eksperymenty i mikstury, ale to wiemy, że to będzie w liceum } \\
\text { i gimnazjum i trzeba się zabezpieczyć. Coś się przelewa. Więcej } \\
\text { rzeczy chemicznych” }\end{array}$ \\
\hline $\begin{array}{l}\text { robotyka, technika, } \\
\text { wynalazki, urządzenia }\end{array}$ & $\begin{array}{l}\text { „Jak się tworzy dane rzeczy. Wynalazki”. „Tak o wynalazkach nie } \\
\text { ma nic”. „Kto wynalazł papier? Co się robi z metalu, ze stali. Jak } \\
\text { powstają pieniądze. Jak się je wytwarza”. Jak się tworzy różne gry”, } \\
\text { „Kto wynalazł światło?” }\end{array}$ \\
\hline
\end{tabular}


Zdaniem dzieci oprócz wymienionych bagatelizowanych lub wykluczonych w podręcznikach obszarów, brakuje w nich także tematyki trudnej, którą szkoła skutecznie marginalizuje. Dzieci uważały, że tematyka trudna jest niezwykle ciekawa, potrzebna, nowa, inna, interesująca, „niepodręcznikowa”, poruszająca bogate i różnorodne treści, o których uczniowie jeszcze się nie uczyli. Tematy, występujące na co dzień w podręcznikach wydawały się uczniom odtwórcze, nużące, schematyczne i stereotypowe. Trudne tematy trzecioklasiści uważali za życiowe, bliskie rzeczywistości, ale często również nieprzyjemne, lękotwórcze, kłopotliwe do rozmowy. Mimo to byli zdania, że powinno się je realizować na lekcjach. Niektórzy uczniowie twierdzili, że tematy trudne, sporadycznie pojawiające się w podręcznikach, nie uwzględniają wszystkich problemów (np. kłótni rodziców), zniekształcają rzeczywistość (np. winą obarczając zazwyczaj chłopców).

Głównymi argumentami podawanymi na rzecz wprowadzania trudnej tematyki na lekcjach była ich nowość i użyteczność.

\begin{abstract}
„A trudne tematy? Rozmawiacie na takie? Mało. Powinno być ich więcej, bo się więcej dowiemy”. „Ja lubię, są ciekawe. Oglądałem wiadomości i mnie to zainteresowało. Są nowe, ale czasami nie do zrozumienia, bo są smutne. I trzeba dotrzeć do źródła. Tak o to mi chodzi, powinny się pojawiać tematy, których jeszcze nie mieliśmy, np. jakieś rzeczy z wiadomości”. „Ja bym chciał, żeby takie były. Bo tam jest bardzo dużo ciekawych rzeczy, o których normalnie nie rozmawia się w szkole”. „Ale inaczej byśmy nie wiedzieli, że ludzie są chorzy i że nie mamy wody na świecie”. „A to są fajne tematy? Tak, bo to też są ludzie i trzeba to wiedzieć”. „A chcielibyśmy jak w innym kraju się dzieci zachowują. Czy nie muszą pracować, jak w innych krajach jest. Wiemy, że to jest trochę smutne, ale trzeba o tym gadać, żeby wiedzieć, jak się pojedzie do tego kraju jak pomóc”.
\end{abstract}

\title{
Konkluzje
}

Uczniowie edukacji wczesnoszkolnej, aktywni uczestnicy procesu edukacyjnego apelują do nauczycieli, twórców podręczników i materiałów edukacyjnych o dostrzeżenie ich potencjału rozwojowego oraz szerokich umiejętności i możliwości poznawczych. Aby móc efektywnie się uczyć, chcą pracy zindywidualizowanej we własnym tempie i na zróżnicowanym poziomie, czemu przeczy codzienność edukacyjna w klasach I-III. Posiadając dużą wiedzę o świecie, uczniowie opowiadają się za odinfantylizowaniem szkoły, rezygnacją z powielającego się, niedostosowanego do ich potrzeb materiału. Chcą zadań dywergencyjnych, otwartych, kreatywnych, rezygnacji z narzucania strategii rozwiązań zadań. Opowiadają się za edukacją nieoderwaną od życia, uwzględniającą ich wiedzę potoczną, osobistą, doświadczenia pozaszkolne i zainteresowania. Pragną wiedzy skontekstualizowanej, pragmatycznej, możliwej do wykorzystania w życiu codziennym.

Postulaty i propozycje zmian podręcznikowych treści proponowane przez trzecioklasistów zgodne są ze współczesną wiedzą pedagogiczną i psychologiczną dotyczącą edukacji dzieci w wieku wczesnoszkolnych. $\mathrm{Z}$ powodzeniem odnaleźć można wspólne mianowniki metodologii dziecięcej oraz wyników badan i analiz prowadzonych przez 
ekspertów, teoretyków i praktyków zajmujących się wczesną edukacją (D. Klus-Stańska, M. Żytko, M. Wiśniewska-Kin, E. Zalewska, M. Nowicka, E. Filipiak). Z roku na rok pogłębia się przepaść między sposobem pracy nauczycieli, działalnością administracji oświatowej oraz założeniami i realizacjami twórców materiałów dydaktycznych dla dzieci. Wszystkie te podmioty, w przeciwieństwie do badaczy wczesnej edukacji, jak i samych uczniów, zdają się nie posiadać wiedzy i świadomości dotyczącej możliwości rozwojowych uczniów klas I-III. Nie doceniają potencjału rozwojowego dzieci.

Infantylne, ogłupiające i niewiedzotwórcze treści w podręcznikach, brak zainteresowania sposobem myślenia dzieci, brak wykorzystania wiedzy osobistej uczniów, wszystko to powoduje ogromne szkody. Uczniowie stopniowo tracą motywację do uczenia się i zainteresowanie szkołą. Nabywają przekonania, że świat wiedzy pozaszkolnej jest znacznie ciekawszy i intrygujący. Nie mogą zrozumieć, dlaczego szkoła - miejsce stworzone dla dzieci, lekceważy ich zainteresowania i potrzeby (Szyller 2016).

Dopóki proces kształcenia w klasach początkowych nie będzie oparty na rzetelnej diagnozie praktyki edukacyjnej i wynikach analiz badawczych, dopóki materiały dydaktyczne nie będą tworzone w zespołach specjalistów rozumiejących specyfikę pracy w klasach I-III i orientujących się w możliwościach rozwojowych dzieci, dopóty świat szkolny i pozaszkolny będą się oddalać. Czy uwzględniając opinie uczniów dokonamy swoistego przebudowania systemu edukacyjnego? Czy upierając się przy swoim, doprowadzimy do sytuacji, w której zbudowanie mostu łączącego dwa wyżej wspomniane światy okaże się niemożliwe? Na powyższe pytania nie znajdziemy dziś odpowiedzi, możemy jednak z dużym przekonaniem i ze smutkiem stwierdzić, że obecnie dyskurs podręcznikowy nie jest dyskursem dzieci.

\section{Literatura}

Bruner J.S. (1978), Poza dostarczone informacje. Warszawa, PWN.

Christensen P., James A. (2008), Research with Children: Perspectives and Practices. London, Falmer Press.

Filipiak E. (red.) (2008), Rozwijanie zdolności uczenia się: wybrane problemy. Bydgoszcz, Wydawnictwo Uniwersytetu Kazimierza Wielkiego.

James A., Jenks Ch, Prout A. (1998), Theorizing Childhood, Teachers College Press.

Jenks C. (2008), Socjologiczne konstrukty dzieciństwa. W: M.J. Kehily (red.) Wprowadzenie do badań nad dzieciństwem. Kraków, Wydawnictwo WAM.

Kehilly M. (2008), Wprowadzenie do badań nad dzieciństwem. Kraków, Wydawnictwo WAM.

Klus-Stańska D., Nowicka M. (2014), Sensy i bezsensy edukacji wczesnoszkolnej. Gdańsk, Wydawnictwo Harmonia.

Michael W.B. (2003), Guilford's Structure of Intellect and Structure - of-Intellect Problem - Solving Models, W: Houtz J., C. (red.) The Educational Psychology of Creativity, Hampton Press, Cresskill.

Szmidt J. (2013), Pedagogika twórczości. Gdańsk, Gdańskie Wydawnictwo Pedagogiczne. 
Szyller A. (2016), Podręczniki zintegrowane dla edukacji wczesnoszkolnej - koncepcja autorów a perspektywa uczniowska, niepublikowana raca doktorska, Wydział Pedagogiczny Uniwersytetu Warszawskiego.

Wiśniewska-Kin M. (2013), Dominacja a wyzwolenie. Wczesnoszkolny dyskurs podręcznikowy i dziecięcy. Łódź, Wydawnictwo Uniwersytetu Łódzkiego.

Wróbel A. (2007), Przestrzenie indoktrynacji. „Problemy Wczesnej Edukacji”, 5/6.

Wygotski L.S. (1971), Wybrane prace psychologiczne. Warszawa, Państwowe Wydawnictwa Naukowe.

Zalewska E. (2013), Obraz świata w podręcznikach szkolnych do klas początkowych. Gdańsk, Wydawnictwo Uniwersytetu Gdańskiego.

Zimny Z. (red.) (1995), Pomiar dydaktyczny jako instrument doskonalenia procesu ksztatcenia (na przyktadzie nauczania początkowego matematyki). Częstochowa, Wydawnictwo Wyższej Szkoły Pedagogicznej.

Żytko M. (2014), Recenzja podręcznika Men, Nasz Elementarz, część 1, klasa 1 szkoły podstawowej. 